\title{
Towards a Poetics of Dwelling: Patrick Kavanagh's Countryside
}

\author{
Marjan Shokouhi
}

University of Tokyo, Japan

Copyright (c) 2019 by Marjan Shokouhi. This text may be archived and redistributed both in electronic form and in hard copy, provided that the author and journal are properly cited and no fee is charged for access.

\begin{abstract}
Patrick Kavanagh's poetry has often been studied in relation to questions of identity and sense of place both in response and reaction to the metanarrative of Irishness popularised during the Irish Literary Revival. New scholarship on Irish poetry, however, has moved beyond viewing Kavanagh's portrayal of the countryside as an antidote to the Yeatsian depiction of the peasant and rural landscape and has made possible a re-reading of Kavanagh's sense of place from an ecocritical perspective. Following the interdisciplinary trend in studying literature in relation to the environment, this paper focuses on the notion of place as a complex socio-environmental entity and addresses Kavanagh's depiction of rural Ireland in his early poetry and novels from the perspective of dwelling. The aim is to highlight the missing element of temporality in reference to the landscape and how Kavanagh's direct engagement with his local community and attention to detail offer a poetics of dwelling, wherein the dweller is an inseparable part of a dynamic and temporal environment.
\end{abstract}

Key Words. Patrick Kavanagh, Ecocriticism, Countryside, Sense of Place, Dwelling, Temporality.

Resumen. La poesía de Patrick Kavanagh se estudia con frecuencia en conexión con cuestiones de identidad y sensación de pertenencia tanto a modo de respuesta como reacción a la metanarrativa de la identidad irlandesa popularizada durante el renacimiento literario irlandés. No obstante, los nuevos enfoques académicos sobre la poesía irlandesa han dejado atrás el Kavanagh de la representación de lo rural como antídoto a los retratos yeatsianos del campo irlandés y sus campesinos, haciendo posible de este modo una revisión del sentido de pertenencia en la poesía de Kavanagh desde el punto de vista de la ecocrítica. Este artículo analiza la noción de pertenencia como una entidad socio-medioambiental compleja y estudia la representación de la Irlanda rural en los primeros poemas y novelas de Kavanagh desde la idea de "habitar" siguiendo tendencias interdisciplinarias consistentes en estudiar la literatura en conexión con el medio ambiente. El objetivo es destacar el elemento perdido de la temporalidad en relación al paisaje y cómo el contacto directo de Kavanagh con su comunidad y su atención al detalle destapan una poética del "habitar", en la cual el habitante es una parte inseparable de un medio cambiante y temporal. 
Palabras clave. Patrick Kavanagh, ecocrítica, campo, sensación de pertenencia, habitar, temporalidad.

\section{Introduction}

Despite the rather late introduction of ecocriticism in the field of Irish studies, the last decade has seen a growing interest in studying Irish literary texts in relation to the environment. Among the wealth of Irish writing which calls for a reconsideration of the old questions of identity and sense of place in Ireland is the work of the Monaghan poet Patrick Kavanagh. While Kavanagh's writing has long been studied in response and reaction to the metanarrative of Irishness, new scholarship on Irish poetry has moved beyond casting Kavanagh's portrayal of the countryside against Yeats's depiction of rural Ireland and instead has enabled a rereading of Kavanagh's sense of place from an environmental perspective. Tim Wenzell in Emerald Green: An Ecocritical Study of Irish Literature, Rosemarie Rowley in "Patrick Kavanagh: An Irish Pastoral Poet in the City", and John Tomaney in "Parish and Universe: Patrick Kavanagh's Poetics of the Local" have to some degree considered Kavanagh's work in the light of current ecocritical discourse. Tomaney, for instance, discusses how Kavanagh's parochial aesthetics offers an "insight into the problem of how we dwell in landscapes and communities in the context of larger human settings" (311). Jody Allen Randolph's ecocritical study of contemporary Irish women's poetry credits Kavanagh as a precursor of "current ecocritical perspectives on Irish poetry" since his observations have challenged and renewed nature poetry in Ireland (57-58). James Mc Elroy in "Ecocriticism and Irish Poetry: A Preliminary Outline" also refers to Kavanagh's texts as "ecological texts" which "embrace those natural wonders which converge in a world of marginal spaces" (59). He further emphasises the "ecological worth" of The Great Hunger, which has been undermined in former analyses pointing to the dark and fatalistic tone of the poem as in Klejs and Gifford's (Mc Elroy 59).

On the other hand, ecocritical scholarship has developed in the last few decades to encompass a more comprehensive view of both the environment and human culture. What counts as ecocriticism today is rather "any theory that is committed to effecting change by analyzing ... thematic, artistic, social, historical, ideological, theoretical" functions of the environment or aspects of it in literary and non-literary texts (Estok 5). In other words, the aim is to understand the myriad ways in which human beings interact with and perceive the environment and to address the current ecological crisis from a cultural perspective. As Randolph has noted in relation to the loss of cultural and historical memory in post-Celtic Tiger Ireland, the "recovery of ecocritical perspectives is the recovery of [Irish] history" (57). As such, an ecocritical consideration of Irish texts like that of Kavanagh's can offer a new appreciation of literary aesthetics while recovering a part of Ireland's rich cultural history - in this case, the rural community of the north, of which Kavanagh was a native.

Aspiring to contribute to the growing ecocritical scholarship in the field of Irish studies, this paper undertakes an ecologically-informed reading of Kavanagh's early poetry and novels from the perspective of Martin Heidegger and Tim Ingold's views on dwelling as a way of being in the world that might bring about an environmental awareness. After a short overview of Kavanagh's early work, this paper investigates the role of Kavanagh's rural poetics in portraying a fresh insight into the simultaneously idealised and marginalised rural community of the north. Patrick Kavanagh's sense of place challenged the revivalist perception of the Irish countryside by drawing attention to the dynamic nature of the land. His work demonstrates how direct engagement within one's immediate socio-environmental community negotiates meaning and sense of place. Through detailed accounts of rural life, 
from the type of soil to the seasonal changes that determined the agricultural economy of the region, Kavanagh's writing intertwined everyday social activities with the region's topography while his panoramic view of the landscape presented an environment that despite its relative social stasis remained in constant flow. In other words, Kavanagh's observations allowed for a viewing of the countryside not as a distant place of the past or an idea celebrated by outsiders, but rather a present reality where a more complex notion of identity and sense of place was and is still at work. Finally, this paper will discuss how Kavanagh's "poetics of dwelling" - to borrow a phrase from Tim Ingold (11) - suggests the possibility of developing a degree of environmental awareness through a realisation of the validity of a sentient and intuitive understanding of human interconnectedness with the ecology of one's dwelling.

\section{The Ploughman Poet and Early Influences}

Patrick Kavanagh was a minor but promising young poet prior to his arrival in Dublin in 1931. His early poetry appeared from 1929 in literary journals and magazines including the Irish Statesman, Dublin Magazine, Irish Times, and Irish Independent. His first volume of poetry Ploughman and Other Poems and his first novel The Green Fool were published before his settlement in Dublin in 1939. A study of Kavanagh's early work highlights major influences in his poetic career among which the influence of the Irish Literary Renaissance and the "myth of Irishness" was not only seen in his writing, but also in his conduct. His sixty-mile walk from Monaghan to Dublin in December of 1931 to meet his mentor George Russell and his "exaggeratedly "countrified" appearance (Quinn 70) were signs of the younger poet's awareness of what the literary society in Dublin was looking for and his readiness to enact it. The "peasant bard" of the literary revival had finally arrived in Dublin to sing of the peasantry. His lack of formal education and humble backgrounds were advantageous in assigning him a role W.B. Yeats and his contemporaries had forged as an image of "authentic" Irish identity, a concept older Kavanagh repudiated in his poetry and prose.

Despite being "a late starter in literature" (Quinn 15) and leaving school before reaching his fourteenth birthday, reading became Kavanagh's major hobby especially after coming into ownership of Reynold's farm at the age of twenty-one. Paddy in The Green Fool and Tarry in Tarry Flynn are both daydreamers who often carry a torn copy of a book with them on the farm. Paddy's account of his library among the briars in the field is an autobiographical account of Kavanagh's early love of poetry and the unusual circumstances of his self-education, which consisted of schoolbook rhymes, street ballads, popular writers in Old Moore's Almanac and Palgrave's Golden Treasury as well as canonical Romantic and Victorian poets. He also read the popular and religious magazines circulated in his native townland of Mucker in Inniskeen, including Sunlight Soap Almanac, The Messengers of the Sacred Hearth, and Ireland's Own.

Early poems such as "Ploughman" and sections from The Green Fool which he later regretted having written register the revival's diction and Georgian pastoral imagery. At times his poetry censures the reality of farm life. According to Antoinette Quinn, Kavanagh's biographer, his early poetry was "a prettified version of reality" built on "deception" (78). Phrases such as "Tranquillity walks with me/And no care", "Joy that is timeless", and "a starlovely art/In a dark sod" (Kavanagh, Collected Poems 7) echo a Yeatsian west-of-Shannon narrative of bliss and beauty. His poetry at this stage is archaic in imagery and outmoded in diction. Holliday calls Kavanagh's early verse a "pale attempt at employing AE's mystical Aestheticism" (140). On the other hand, this early sentimentality captured at its best what Oona Frawley has called "the mood of a generation that was shifting the population centres of Ireland" (85-86). High unemployment rates, emigration, and celibacy continued to drain the 
countryside in the first decades of the twentieth century and even after Kavanagh had left Monaghan for Dublin.

Kavanagh himself called his early meditative verse "mere juvenilia" (Selected Prose), yet what is rewarding about his early vision is the employment of an imagery derived from direct engagement with his immediate surroundings. He is a keen observer of what seems to be a pastoral landscape populated with birds and trees. One of his earliest poems, "Four birds", is a descriptive verse about familiar birds in the poet's environment - kestrel, owl, lark, and corn-crake. Compared to Yeats's bird imagery in The Wanderings of Oisin, for example, - the osprey, eagles, seagulls, etc. - Kavanagh's birds carry no supernatural significance; at most, they imbue the marginalised landscape of rural Ulster with a tangible romantic touch. Kavanagh's pastoral, or antipastoral as one might argue, is a depiction of the country's merits and beauties as well as its banalities and hardships. His addressees are old wooden gates as well as blackbirds, trees, and seasons. At one time, spraying the potatoes in Tarry Flynn becomes the most pleasing and heroic of tasks, while on another occasion it turns into a denigrating activity on Reilly's farm, with Tarry clad in his patched trousers and his back soaked from the leaking spray can.

According to Seamus Heaney, Kavanagh's early poetry is under the influence of a Blakean notion of consciousness in Songs of Innocence and Experience. Verses from Tarry Flynn and poems like "Shancoduff", "A Christmas Childhood", and "Spraying the potatoes" reflect "the growth of a poet's mind" (120). In other words, Kavanagh's sense of place invokes a mixed feeling of attachment and alienation at the same time. The early poems construct the very dynamics of a landscape which perhaps for the first time since the Revival emerges as alive and temporal. Kavanagh achieves this through an act of disclosure or what may be termed as a dwelling perspective, one in which the narrator is the figure in the landscape. Dwelling is more than inhabiting the earth; it is a way of communicating with and perceiving the environment particular to human beings as the only living phenomena conscious of their existence. Dwelling is dynamic; it is a process that involves "the long-term imbrication of humans in a landscape of memory, ancestry and death, of ritual, life and work" (Garrard 108).

In Heideggerian etymology, dwelling is closely connected to Dasein, being in the world, and characterised by "sparing and preserving" the land (Heidegger 149; original emphasis). The dwelling perspective in Kavanagh's poetry manifests a complex relationship between the poet-farmer and his environment and offers a view of the landscape and peasantry beyond revivalist and colonial stereotypes. Kavanagh's intuitive knowledge of the countryside and attention to detail can also be interpreted in relation to Tim Ingold's "poetics of dwelling" (11), a derivative of Martin Heidegger's later philosophy and influenced by the works of prominent anthropologists Gregory Bateson and Claude Lévi-Strauss.

In The Perception of the Environment, Ingold questions the view of the environment as dead, unengaging, and separate from humans and acknowledges instead its dynamism, relativity, and temporality through the following principles: First, the environment is always a relative term; "that is, to the being whose environment it is". Second, the environment is a process rather than a complete entity in itself and as long as "environments are forged through the activities of living beings ... they are continually under construction". Third, there is a fundamental difference between "environment" and "nature" which "corresponds to the difference in perspective between seeing ourselves as beings within a world and as beings without it" (20; original emphasis). As the remainder of this paper will discuss, Kavanagh's perception of the country comes from within that environment, hence acknowledging the mutability and agency of the land through active engagement, which often translates into educating the reader where to look. 


\section{The Education of Attention - Kavanagh's Eye for Detail}

Kavanagh was a keen observer of the living and non-living entities of the landscape. Details that at first might seem cumbersome become indispensable to the perception of the poet's environment. They are not employed as decorative devices adding to the ambience of rural life nor serving the purpose of poetic description per se; rather the poet's watchful eye in Monaghan and later in Dublin helped create the tangible experience of being part of a certain environment - rural or urban - built upon personal experience. The landscape is enlivened with trees, birds, crops, hills, and rivers; the cityscape is characterised by street names, canal banks and bridges, and both are peopled with characters such as Tarry Flynn, Paddy, Patrick Maguire, lovers, and passers-by.

Seamus Heaney compared Kavanaghs' attention to detail to "the child's open-eyed attention to the small and the familiar" in "A Christmas Childhood". His sensibility "is acutely of its own time and place, and his region is as deep not as its history but as his own life in it" (142). This is while the majority of the writers during the Irish Renaissance and afterwards relied on the notion of land as a reliable entity out of a "desperate hope" (Sheeran 287) to bypass the country's turbulent history and to restore stability and continuity to a nation of diverse social, religious, and political convictions. Kavanagh's poetic imagination, however, is rooted in his personal environment and his narratives, for the most part, remain free of the cultural anxiety that characterised the previous generation's engagement with questions of land and identity. His relationship with place oscillates between love and hate, a sense of attachment accompanied by frustration. His poetic personae, the embodiment of this complicated relationship, are often trapped in what seems like a stagnant rural landscape. However, this stasis is a result of the oppressive social mechanisms that govern the countryside; furthermore, the sense of entrapment is reinforced by the harsh realities of farming and rural life. The actual landscape, on the other hand, remains in constant change and Kavanagh's attention to detail offers an understanding of the human-environment relationship from the perspective of a participant in the socio-environmental matrix of life in the countryside.

Instead of imposing his view of rural Ireland as a fixed construction, Kavanagh teaches the reader where to look and by drawing attention to colours, sounds, scents, and textures helps transform the passive reader into an active observer who participates in the discovery of meaning embedded in the environment. An example is Tarry's watchful eyes through whose moving vision Kavanagh discloses a panoramic rather than a flat view of the landscape. One learns about the hills in the distance, the potato pit, the briars in the corner of the field as well as the country people who are engaged in certain activities. He instructs the reader to look "around" rather than to look "at". This is what Ingold calls "the education of attention", a phrase he borrows from Gibson in order to explain how the environment is understood through sensory perception and how knowledge is transferred in an ongoing engagement within the environment. Referring to the transmission of knowledge from one generation to another in tribal cultures, Ingold emphasises the importance of showing as a way of instructing the inexperienced observer about the knowledge inherent in the environment:

To show something to somebody is to cause it to be seen or otherwise experienced whether by touch, taste, smell or hearing - by that other person. It is, as it were, to lift a veil off some aspect or component of the environment so that it can be apprehended directly. In that way, truths that are inherent in the world are, bit by bit, revealed or disclosed to the novice. What each generation contributes to the next, in this process, is an education of attention (Gibson 1979: 254). Placed in specific 
situations, novices are instructed to feel this, taste that, or watch out for the other thing. Through this fine-tuning of perceptual skills, meanings immanent in the environment - that is in the relational contexts of the perceiver's involvement in the world - are not so much constructed as discovered. (21; my emphasis)

The education of attention implies a type of learning that brings about knowledge. One does not become simply "more knowledgeable" through the accumulation of information. Rather, knowledgeability consists "in the capacity to situate such information and understand its meaning, within the context of a direct perceptual engagement with our environments. And we develop this capacity ... by having things shown to us" (Ingold 21; original emphasis). For Kavanagh, the knowledge of the countryside comes from the inside. Whether viewing it from within the parish, on the field while spraying the potatoes, or reminiscing the harvest season while in Dublin - hence reliving the moments through memory and association - he is a participant in his own narrative. He is able to present a vista, the understanding of which is inseparable from an understanding of the seasons, crops, quality of soil, harvest time, trees, birds, and cattle. Take for instance the poet's sensitivity to the seasonal changes and the time of the year wherein a specific activity is taking place. The poems "After May", "April", "March", "April Dusk", and "October 1943" as obvious from their titles are seasonal poems in which the mention of the month binds the activity to a living environment. The time of the year informs the reader - the novice - whether it is the calving season or harvest time, if it is time for planting a tree or harrowing the field; in other words, the environment is built around these time-specific activities.

Regardless of whether these changes are cyclical like that of the seasons or embody more permanent and serious alterations such as the advance of farming life in the parish, Kavanagh's countryside remains dynamic. This element is present in most of his early poetry which often reflects the growth of an entity interconnected with that of another. Examples include "To a Late Poplar", "Beech Tree", and "Poplar Memory", poems that deal with Kavanagh's passion in real life; i.e. trees. In "Beech Tree", for instance, he writes of planting a beech in February, protecting it from "goats with wires" and waiting for it to come with leaves during the spring (9). In "The Poplar Memory" the planter is the poet's father and the tree becomes a point of reference to indicate the passage of time.

Temporality is one of the primary characteristics of the landscape. Ingold uses the term "taskscape" - "a pattern of dwelling activities" - to describe the temporality of the landscape through the activities that take place there. To make his point clear, he offers an interpretation of Pieter Bruegel's The Harvesters (1565). The painting depicts the month of August where a group of peasants are working on the land or resting by the shadow of a pear tree. The proper use of colours and the portrayal of certain agricultural tasks make the painting a miniature example of the real landscape. Referring to human activity as well as the natural and artificial phenomena such as the nearby tree and the church in the distance, Ingold draws attention to how the landscape is under formation as time passes and how people "shape the landscape" as they dwell on it (157). In specific, the pear tree becomes a point of reference which "draws the entire landscape around it into a unique focus":

In a sense ... the tree bridges the gap between the apparently fixed and invariant form of landscape and the mobile and transient forms of animal life, visible proof that all these forms, from the most permanent to the most ephemeral, are dynamically linked under transformation within the movement of becoming of the world as whole. (205)

Similar to Ingold's interpretation of the pear tree in the painting, Kavanagh's taskscapes indicate the temporality of the environment. As Bruegel's pear tree embodies a history of 
development from its own growth to the passage of time in the village, Kavanagh's landscapes are populated with living and non-living entities whose existence is bound with that of one another. Nevertheless, Kavanagh's countryside is austere and free from idealisations in Bruegel's genre paintings which capture a pastoral environment modelled on a period of prosperity in the Netherlands. While Kavanagh's view of the field and peasants emanate from an insider's vantage point, Bruegel, as Walter Gibson believes, was inclined to "depict peasants very much as a wealthy landowner would have viewed them, as the anonymous tenders of his fields and flocks" (157-58). Kavanagh's personae, on the other hand, do have a name and it is through their vista that the reader is offered a glimpse of the farming community and their activities.

\section{The Farming Community: Acting, Perceiving, Dwelling}

Many of Kavanagh's personae are members of a farming community. Before harbouring dreams about becoming poets, both Paddy and Tarry are minor farmers who participate in the social and agricultural activities of their community. The majority of Kavanagh's poetry from 1929 to 1946, including "The Hired Boy", "Spraying the Potatoes", "To the Man after the Harrow", "Plough Horses", "Temptation in Harvest", and "In Memory of My Mother" refer to an aspect of farming and agriculture. If as Ingold mentions, "ways of acting in the environment are also ways of perceiving it" (9), the perception of Kavanagh's environment is dependent upon the perception of the farming community in rural Monaghan and the activities therein; i.e. harrowing, seeding, spraying, tilling, and harvesting the field, selling and bargaining in local fairs and markets, taking care of poultry and cattle, going on pilgrimage, storytelling, dancing and other local events. These details alongside the gossip and rumours circulating in the parish and nearby towns take such importance that they no longer seem to be a backdrop to an unfolding story; rather they become the story, a story of humble origins that becomes spectacular in the poet's treatment of the banal and mundane. Tarry's most romantic and poetic revelations come to him while he is busy pulling out turnips or draining the land. The origins of the "lea green poem" (better known as "The Ploughman") comes from "A kicking mare in a rusty old plough tilling a rood of land for turnips" (Kavanagh, The Green Fool 219).

In the chapter "Life and Death" of The Green Fool, Paddy describes the ins and outs of slaying a pig and selling it at the local market (181-83). This information is described with such precision and force that one is bound to ask why Kavanagh inscribes details of farming life in a novel addressed to an urban readership in London and Dublin. This information, far from constructing a rural setting or idealising the country tasks, instructs the reader of the reality of life in rural Ireland in the first decades of the twentieth century. The novel offers a critique of the restrictive rural community of Ulster and the marginalisation of small Catholic villages and townlands in a country soaring towards modernism.

It is noteworthy that the gradual modernisation of farming methods in Ireland did not take place until the "widespread diffusion of the tractor" after World War II (O'Dowd 121). What was available at the time were a few simple, yet highly valued old farm tools: "a spade, a rake and a shovel" (21). The bigger farms also required the use of a "plough, harrow and roller". The introduction of the improved equipment was not often welcomed at first since the alterations did not necessarily mean a more feasible farming method but one that broke with tradition. Of this equipment, the plough has been the single oldest farming tool in Ireland and "modifications made to it mirror the development of Irish agriculture" (122). When the improved plough was introduced, it often steered some unwelcome reactions. In The Green Fool, Paddy reminds the reader of the deep respect the country people have for the plough: 
"In a quiet way it was an idol. To tamper with a plough was a dark sin. 'The unluckiest thing ye ever done', I was told" (96).

Borrowing farm equipment and animals for ploughing was a common practice in the countryside. Kavanagh continuously refers to borrowing a donkey from one of the neighbours: "Kerr's ass" in a poem of the same name and Cassidy's ass in The Green Fool are two examples. Other than farming, participation in fairs and local markets were the major source of business and livelihood in the countryside. In "In Memory of My Mother", Kavanagh remembers his late mother as not "lying in the wet clay"; rather the act of remembrance takes place through the dynamism of walking "among the poplars" on her "way to the station", "Going to second mass" or meeting the poet "On a fair day by accident, after/The bargains are all made" (Kavanagh, Collected Poems 129). The memories are kinaesthetic and the dynamism of the environment in which the poet commemorates his mother gives her an air of life and mobility rather than death.

The introduction of radio and television in the 1960s replaced many of the old methods of entertainment in the country, including storytelling, singing, and dancing, which are other details mentioned by Kavanagh. Another important component of rural life was and to some extent continues to be visiting holy wells and going on patterns, i.e. a pre-Christian ritual which was later adapted to the Christian practice of devotion to a patron saint of a parish on a feast day or the nearest Sunday, called a Pattern Sunday. Lough Derg, which is among Kavanagh's longer poems engages with this old practice and provides an insight into the marginalised Catholic community of the North inflicted with unemployment, high celibacy rates, and poverty. In this poem, the "banal beggary" of the country people who have travelled from Cavan, Leitrim and Mayo and "From all the thin-faced parishes where hills/Are perished noses running peaty water" (Kavanagh, Collected Poems 107) is described in detail to vex the urban reader whose view of the countryside has nothing in common with the view of a suffering people to whose silent prayers Kavanagh has given a voice. There is an underlying critique of a social system which has caused widespread unemployment, hunger, celibacy, and poverty. Kavanagh gives importance to the "mean" and banal longings of men and women who have travelled far, barefooted or with gravel in their boots for redemption. Their redemption, as he bitterly remarks in The Great Hunger, comes only when they are freed from the knot tying their feet to the wet, cold clay of their parish.

The word "clay" is arguably the most pronounced detail of Kavanagh's countryside, which embodies the landscape as a lived-in and living environment. When in "Municipal Gallery Revisited", Yeats wrote "All that we did, all that we said or sang/Must come from contact with the soil" (603), the soil was for him more of a symbol than a tangible reality. In contrast, Kavanagh writes of the real thing; the touch of the clay is emphasised throughout his novels and poems. It is noteworthy that soil often denotes fertile ground whereas nothing grows in clay; however, the significance of clay shifts in Kavanagh's reference and at times both words are used interchangeably and in relation to similar vocabulary. In "A Christmas Childhood", he writes about eating "the knowledge that grew in clay" (Kavanagh, Collected Poem 39), In "Temptation in Harvest" the clay has the capacity "to seduce" the poet's heart (121). The "Stony Grey Soil of Monaghan" is an object of love and hate (38). The Great Hunger ends with "the apocalypse of clay" (89).

Adjectives are of utmost importance. The sod is described in various places as "dark", "sticky", "stony", "hard", "good", "fertile", "wet", and the like. In The Green Fool, Paddy makes frequent reference to how the soil feels in his hands: "The soil was heavy, sticky, and lumpy". His own mind is described as "clay-heavy" (103, 244). Similar adjectives such as "mud-gloved fingers", "Clay-wattled moustache", "twisting sod" and "Clayly hours" (Kavanagh, Collected Poems 64-69) set the tone for Kavanagh's critique of the restrictive rural community in The Great Hunger. The poem is dominated by the use of the word "clay", 
which from the very beginning registers an authoritative, biblical tone: "Clay is the word and clay is the flesh" and after a series of apocalyptic observations the poem ends with "the hungry fiend" who "sings the apocalypse of clay/In every corner of this land" (89).

The landscape is stripped bare of the former romantic associations that depicted the soil and the peasants' adherence to it as a sign of authenticity in Irish culture; so is the peasant liberated "from the cosy imagination of the nation into the painful reality of contemporary existence" (McDonagh 41). The image of the heroic countryman, the peasant bard, the gleeman of the Yeatsian canon is now reduced to a bunch of "potato-gatherers" moving like "mechanized scare-crows" where the poet struggles to find "some light of imagination" in the "wet clods" (Kavanagh, Collected Poems 63). The root of Paddy Maguire's tragedy, the sixtyyear-old bachelor who toils his days on a farm in The Great Hunger, "lies in the violation of human nature by such forces as family, morality and religion" (Zhou 82).

The frequent use of the term clay is a manifestation of the cruel grip of nature over Kavanagh's personae. Nature turns against Tarry time and again; an example is when he wishes for the rain to come down in "bucketfuls" so he can miss the local event but the day proves fair and sunny (Kavanagh, Tarry Flynn 150). Nature's grip with which Kavanagh ends the story of Tarry Flynn is similar to the doomed destiny of Maguire in The Great Hunger. Removed to the degree of beasts and vegetables, the peasant's bond with nature remains inseparable even in death:

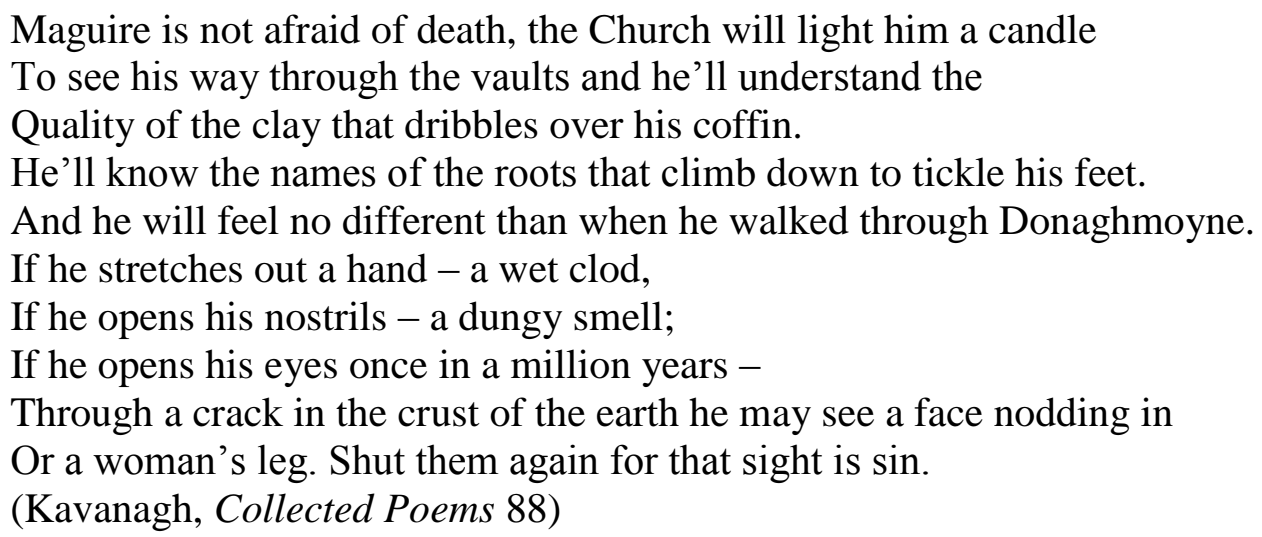

Maguire's clay-bound death is a version of Tarry's clay-bound life. In the last chapter of Tarry Flynn, we read: "The present tied him in its cruel knots and dragged him through bushes and briars, stones and weeds on his mouth and nose" (174). Similarly, in The Green Fool, Paddy talks about the difficulty of freeing oneself of the grip of the land and its counterintuitiveness to literary imagination: "The land, when once it gets a grip on a man, will not easily let him go. The land is jealous of literature, and in its final effort to hold a poet offers him, like a despairing lover, everything, everything" (245).

"Stony Grey Soil", "Inniskeen Road, July Evening", and "Shancoduff" are among other parochial poems which challenge an outsider's view of the countryside as "nature" and invoke instead a sense of place based on a conflicting relationship amidst attachment to and alienation from one's environment. In "Stony Grey Soil", for instance, the poet addresses his native land and its features with a degree of directness, precision, and intimacy which testifies his love for rural Monaghan underneath the contempt expressed for the same place which has hindered his growth and robbed him of youth and love for other things:

O stony grey soil of Monaghan

The laugh from my love you thieved

You took the gay child of my passion 
And gave me your clod-conceived.

$\cdots$

You flung a ditch on my vision

Of beauty, love and truth.

O stony grey soil of Monaghan

You burgled my bank of youth! (Kavanagh, Collected Poems 38)

At the depth of Kavanagh's frustration with what detains him from growth, there is a "clodconceived" passion that makes him the poet he is. Later in life, Kavanagh regretted having left his farm and settled in Dublin to pursue his career as a poet. The nostalgic tone of "Temptation in Harvest", for instance, represents the point of view of a person who has reconciled with his early object of love/hate - the land. The cruel grip of nature in the line "the devilry of the fields" is now transformed into the poet's passionate care for his farming life: "The ricks are now my care" (Kavanagh, Collected Poems 121,122). The complexity of this relationship presents not only a deeper understanding of the poet's marginalised rural landscape but also points to the complex nature of the human-environment interaction in general. While there is a sense of reconciliation between the poet and his rural and urban landscapes in later poems, his early narratives also include a sense of place that amidst the oscillation between attachment and alienation conveys a love of the land and a respect for its nonhuman life. Topophilia is best exemplified in Kavanagh's parochial sense of place and the sentient ecology of his personae in Tarry Flynn and The Green Fool. In contrast to the rationalistic and dichotomous perception of man as separated from the environment, a "sentient ecology" (Anderson 116-117; qtd. in Ingold 25) embeds humans as organisms inhabiting the environment. The following section elaborates on Kavanagh's "ingrained sense of nature" to quote Randolph (56) and explains how awareness towards the environment which should bring about a degree of care and responsibility originates from an active knowledge of the local, which brings to mind the "Think globally, act locally" slogan celebrated by environmentalists.

\section{Kavanagh's Sacerdotal Care and Parochial Sense of Place}

In a lecture delivered at Ulster Museum in 1977, Seamus Heaney drew a line between two different senses of place in Irish poetry: "One is lived, illiterate and unconscious, the other learned, literate and conscious" (131). In comparison to Montague's learned etymology of placenames or Hewitt's rationalisation of his northern roots, Kavanagh's sense of place stakes out a personal landscape, denuded of tribal or etymological implications. "Mucker, Dundalk, Inniskeen, "provide no frisson beyond the starkness of their own daunting, consonantal noises" (140).

Indeed, what sets apart Kavanagh's view of the landscape is his invocation of a sense of place that is parochial. The "parochial mentality" according to the poet himself is based on "the right type of sensitive humility" towards one's place and is not to be mistaken for provincialism (Kavanagh, Selected Prose 237). "The provincial has no mind of its own" and looks toward the metropolis; the parochial, on the other hand, "is never in doubt about the social and artistic validity of his parish" (10). Kavanagh does not offer a history of placenames, neither do his land/cityscapes carry nuances of Irish nationalism. His ecology offers a "felt knowledge of place" (Heaney 132), a knowledge that is personal and based on the poet's momentary response to his surroundings. The hills around Reynolds farm were among Kavanagh's most beloved places. In The Green Fool, this love is reflected in Paddy's passion for the hills surrounding Rocksavage farm: 
There were good names on these hills even though their soil was sticky and scarce of lime. Poets had surely put the names on them. Translated from the Gaelic they were: 'The Field of the Shop', 'The Field of the Well', 'The Yellow Meadow', 'The Field of the Musician'. (Kavanagh, The Green Fool 204; my emphasis)

At first glance, Kavanagh seems to be a namer in the fashion of Yeats. His beloved hills remind one of the "Seven Woods of Coole" and Yeats's enthusiasm in their mythology. The Monaghan placenames - Gortin and Ballyrush, Dundalk and Drumnei - have a slight undertone of Yeats's Colooney, Coole, or Innisfree; yet these places are not seen by the poet as more "Irish" or "authentic" than any other place. In his famous essay "Self Portrait", Kavanagh insisted that he had "no belief in the virtue of a place" (Kavanagh, Selected Prose 309). There is no pretension or learned invocation of a landscape in Paddy's naming of the hills except for his personal response; the names of the hills are simply remarked as "good" names. Nevertheless, through his parochial perspective that deals with the local, Kavanagh was able to give "the unremarkable countryside around Inniskeen a remarkable presence in the Irish literary landscape" (Gilsenan Nordin 49-50).

Kavanagh's understanding of his local flora and fauna is free from the learned knowledge of the books. In "On Reading a Book of Common Wild Flowers" the poet confesses his love for the fleabane, the burnet saxifrage, and the autumn gentian long before knowing their names:

O the greater fleabane that grew at the back of the potato pit:

I often trampled through it looking for rabbit burrows!

The burnet saxifrage was there in profusion

And the autumn gentian-

I know them all by eyesight long before I knew their names

We were in love before we were introduced.

(Kavanagh, Collected Poems 200; my emphasis)

Kavanagh is more of a knower than a namer. His sense of place is "emotional and definitive" (Heaney 145) and the knowledge of his surroundings is practical and personal. According to Mc Elroy, "Whether Kavanagh recounts the significance of local plant life" in this poem "or celebrates, as he does in the later 'Canal Bank Walk' ... his overriding concern is with the parish as a limited and liminal - but luminous - habitat space" (59). The use of personal possessive adjectives in poems such as "Stony Grey Soil" and "Inniskeen Road, July Evening" is indicative of a sense of intimacy between the poet and his surroundings, which in terms of Leopold's "land ethics" is the first stage of an ecologically-evolved response to the environment. In "Shancoduff", the same hills that have been forsaken by "water-hen and snipe" are referred to as "my hills" (Kavanagh, Collected Poems 21; my emphasis); they are the poet's "Alps" just as the stretch of road in "Inniskeen Road, July Evening" is his kingly possession: "A road, a mile of kingdom, I am king/ Of banks and stones and every blooming thing" (21).

For Heaney the single word "blooming" in the above line is key to the ambiguous stance of the poet somewhere between attachment and detachment, of being "at once marooned and in possession" (118). In the northern dialect, blooming means bloody or annoying while the reference to banks and stones could also imply thriving and growing. There is a hidden note of detachment in the unspectacularness, solitude, and poverty of the hills in "Shancoduff", yet Kavanagh is perhaps best in touch with his dwellings as when he seeks detachment, a theme that is at the centre of both his novels.

Paddy's love for Rocksavage farm and its surroundings comes from working on the 
field and his intimate knowledge of the place: "I worked in all the fields of Rocksavage and developed a homelover's sentiment for them. I knew every corner of those fields, and every well and stream" (Kavanagh, The Green Fool 62). He later speaks about the important place of the farm in his life and particularly addresses the significance of the trees:

Rocksavage filled a great place in our lives. Before the War there were thousands of beautiful trees on the farm. Close to our school these trees leaned over the wall and dropped us nuts - monkey-nuts for making toy-pipes, horse-chestnuts of which we made whistles and hazel-nuts which we ate.

Then came the timber hunger and the trees began to fall.

'O what will we do for timber?

The last of the woods are down'

No wonder the old Gaelic poet, lamenting the destruction of the woods of Kilcash sang so loudly. (63)

Paddy's view of the trees, from a schoolboy's perspective to the later lyrical appreciation of the beauty in nature, awakens a sense of care the lack of which is associated with barbarism:

Rocksavage trees were sold by auction. The man who bought one cut down five as there was nobody to stop him. Father did not buy any of the trees. There were no young, strong men in our house to help. There was no love for beauty. We were barbarians just emerged from the penal days. (Kavanagh, The Green Fool 62)

Paddy's sentient ecology is not restricted to trees. After ownership of the farm, he writes of the wildness of the briars and of the place being "a sanctuary for hares and rabbits" and how he does not "disturb their briary haunts" (207). During the Carrick fair, where Paddy and his friend are hired to work as farm hands, he is shattered by the cruelty of the owners towards their animals. He does not understand what "feeding" signifies when one of the owners complains about donkeys. His innocence is immediately ridiculed.

'Oats and hay you give them, I suppose?'

The answer is: 'Hay and oats be no good to asses,' he said.

'The stick is what they get when they begin to get drowsy. Why, man, if ye saw an ass after his feed he's as lively as a red-bellied bee in a June meadow. If ye come with me I'll show ye the asses a-feedin'.'

'I don't want to see it,' I said. (Kavanagh, The Green Fool 118)

Paddy's sensitivity towards animals continues throughout the volume. In "The Outlaws" chapter, he narrates the illegal attempt to catch salmon in the river through "salmon-gaffing" and calls it "cruel work" (139). Similar passages run through Kavanagh's body of work, where the poet's appreciation and sympathy for his environment present a sentient understanding of the country's hills and rivers as well as its domestic and wild animals. There is an environmental awareness in Kavanagh's poetry and prose that does not originate from adherence to any institution or movement; rather, it is influenced by a sense of place based on the poet's intuition and direct contact with the land. In contrast to the recent proenvironmental or environmentally-acknowledged narratives, Kavanagh's sentient ecology does not carry any explicit ecological message. It is built on individual response and sensitivity to his environment. This is what Heaney refers to as Kavanagh's "pastoral care" which in his view is as much sacerdotal as it is literary (121). 


\section{Conclusion}

While Kavanagh's departure from the influence of the Irish Literary Revival does not take place until later in his poetic career, his early work showcases a sense of place rich with nuances absent from revivalist narratives. His landscapes and characters were contemporaneous with his own time and place. The backward-look, characteristic of the time, was missing from his poetry. Even when poems become nostalgic and retrospective as in "Temptations in Harvest", the nostalgia is personal and delivers a sense of homesickness. Kavanagh's countryside can serve as an example of how one's perception of the environment changes in accordance to one's distance or proximity to it as well as being dependent on one's level of engagement. The poet's ability to see beyond the picturesque and scenic features of the landscape and his insight into the social reality of the rural community of southern Ulster emancipated his poetry from the idealisations which had dominated the literary representations of rural Ireland since the nineteenth century. The rural Irish landscape does not represent nature or authenticity in Kavanagh's work, for to repeat Ingold "the world can only exist as nature for a being that does not belong there" (20). Kavanagh was a dweller and in contrast to the tourist and outsider's perception of the countryside, his remained first and foremost a dwelling; an environment in the making.

\section{Works Cited}

Anderson, David Gregory. Identity and Ecology in Arctic Siberia: The Number One Reindeer Brigade. Oxford: Oxford University Press, 2000.

Estok, Simon C. "Ecocriticism in an Age of Terror". CLCWeb: Comparative Literature and Culture 15.1 (2013): 1-9.

Frawley, Oona. "Kavanagh and the Irish Pastoral Tradition". Patrick Kavanagh. Ed. Stan Smith. Dublin: Irish Academic Press, 2009: 72-92.

Garrard, Greg. Ecocriticism. New York: Routledge, 2004.

Gibson, Walter. Bruegel. London: Thames and Hudson, 1977.

Gilsenan Nordin, Irene. "The Place of Writing in the Poetry of W. B. Yeats and Patrick Kavanagh". Nordic Journal of English Studies 2 (2014): 43-56.

Gifford, Terry. Green Voices: Understanding Contemporary Nature Poetry. Manchester: Manchester University Press, 1995.

Heaney, Seamus. Preoccupations: Selected Prose, 1968-1978. New York: Farrar, Straus, and Giroux, 1989.

Heidegger, Martin. Poetry, Language, Thought. Transl. and Intro. Albert Hofstadter. New York: Harper and Row, 1975.

Holliday, Shawn. "Patrick Kavanagh (1904-1967)". Modern Irish Writers: A Biocritical Source Book. Ed. A. G. Gonzalez. Westport: Greenwood Press, 1977.

Ingold, Tim. The Perception of the Environment: Essays on Livelihood, Dwelling and Skill. London \& New York: Routledge, 2010.

Kavanagh, Patrick. Collected Poems. Ed. A. Quinn. London: Penguin Books, 2005.

—. A Poet's Country, Selected Prose. Ed. A. Quinn. London: Penguin Books, 2003.

- The Green Fool. London: Penguin Books, 2001.

- Tarry Flynn. London: Penguin Books, 1978.

Klejs, Lene. "Seed Like Stars: Kavanagh's Nature”. Eire-Ireland 18.1 (1983): 98-108.

Leopold, Aldo. A Sand County Almanac and Sketches Here and There. New York: Oxford University Press, 1987. 
McDonagh, John. "The Great Pyramids of Carlingford Lough: John Hinde and the De Valerian Utopia”. Representing Ireland: Past, Present and Future. Eds. A. O’MalleyYounger and F. Beardow. Sunderland: University of Sunderland Press, 2005: 37-46.

Mc Elroy, James. "Ecocriticism and Irish Poetry: A Preliminary Outline". Estudios Irlandeses 6 (2011): 54-69.

O'Dowd, Anne. "Folklife and Folk Traditions". The Irish Countryside: Landscape, Wildlife, History, People. Ed. D. Gillmor. New York: Barnes and Noble Books, 1989: 121-160.

Quinn, Antoinette. Patrick Kavanagh: A Biography. Dublin: Gill and Macmillan, 2001.

Randolph, Jody Allen. "New Ireland Poetics: The Ecocritical Turn in Contemporary Irish Women's Poetry". Nordic Irish Studies 8 (2009): 57-70.

Rowley, Rosemarie. "Patrick Kavanagh: An Irish Pastoral Poet in the City". Journal of Ecocriticism 1.2 (2009): 92-103.

Sheeran, Patrick. "Landscape and Literature". Journal of the Galway Archaeological and Historical Society 5 (2003): 151-158.

Tomaney, John. "Parish and Universe: Patrick Kavanagh's Poetic of the Local". Environment and Planning: Society and Space 28 (2010): 311-325

Wenzell, Tim. Emerald Green: An Ecocritical Study of Irish Literature. Newcastle upon Tyne: Cambridge Scholars Publishing, 2009.

Yeats, William Butler. The Variorum Edition of the Poems of W. B. Yeats. Eds. P. Allt and R.K. Alspach. New York: Macmillan, 1966.

Zhou, Weigui. "Paradoxical Rural Imagination of Ireland and Its Cause in The Great Hunger". Studies in Literature and Language 7. 2 (2013): 79-84.

Received: 12 November 2018 Revised version accepted: 11 February 2019

Marjan Shokouhi is an Assistant Professor at the College of Arts and Science, University of Tokyo. Her fields of interest include ecocriticism, Irish studies, comparative literature, and creative writing. In 2017, she co-edited a special issue on Irish folklore for Estudios Irlandeses with Dr. Audrey Robitaillié. Her other publications include reviews and essays on W.B. Yeats, Samuel Beckett, Patrick Kavanagh, Deforestation in Ireland, etc.

marjan.shok@gmail.com 